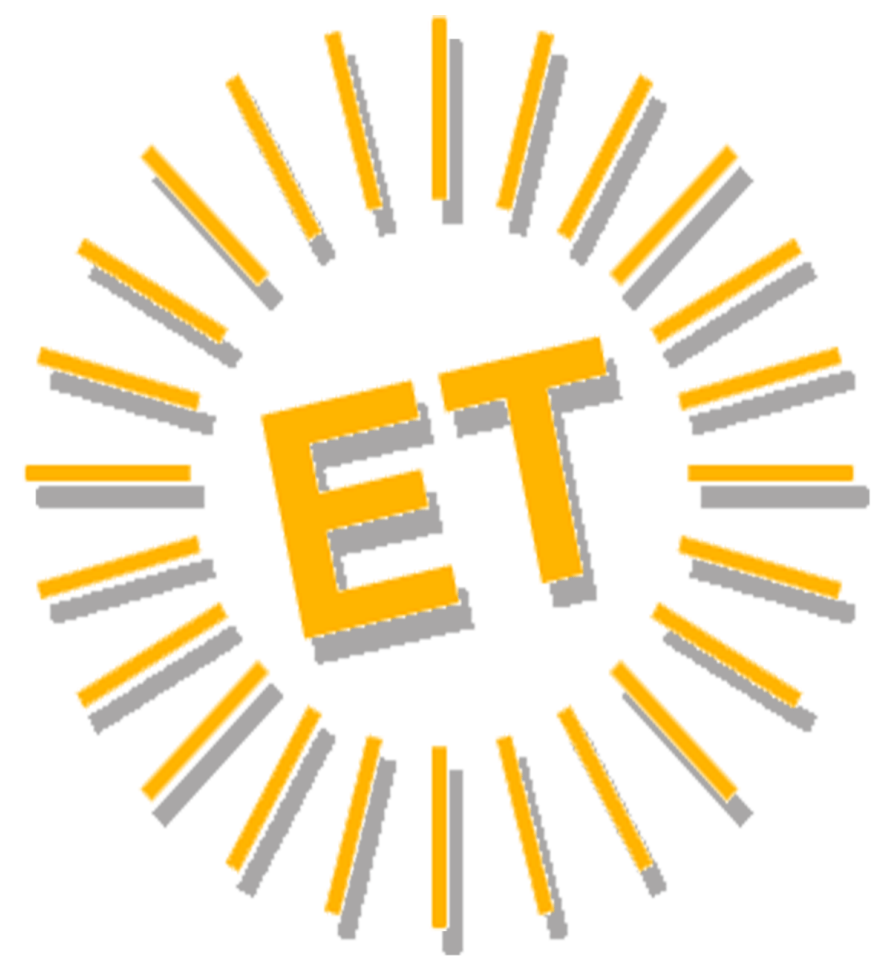




\section{Editorial Team}

\section{Editor in Chief}

Alfonso Vargas-Sánchez, University of Huelva, Spain

\section{Associate Editor}

Mirko Perano, Reald University College, Albania

\section{Books Review Editor}

Brendan Paddison, York St. John University, United Kingdom

\section{Secretariat}

Elena García de Soto, University of Huelva, Spain

Cinta Borrero-Domínguez, University of Huelva, Spain

\section{Style reviewer and text editor}

Anestis Fotiadis, I-SHOU University, Taiwan, Province of China

\section{Editorial Board}

José Manuel Alcaraz, Murdoch University, Australia Mario Castellanos-Verdugo, University of Seville, Spain José Antonio Fraiz-Brea, University of Vigo, Spain José Manuel Hernández-Mogollón, University of Extremadura, Spain

Tzung-Chen Huan, National Chiayi University, Taiwan, Province of China

Shaul Krakover, Ben Gurion University, Israel Jean Pierre Levy-Mangin, University of Quebec, Canada Tomás López-Guzmán, University of Córdoba, Spain Yasuo Ohe, Chiba University, Japón María de los Ángeles Plaza-Mejía, University of Huelva, Spain Nuria Porras-Bueno, University of Huelva, Spain João Albino Silva, Algarve University, Portugal

\section{Advisory Board (Spanish Members)}

Juan Manuel Berbel-Pineda, Pablo de Olavide University, Spain César Camisón-Zornoza, Uniersity of Valencia, Spain Enrique Claver-Cortés, University of Alicante, Spain María Teresa Fernández-Alles, University of Cádiz, Spain José Luis Galán-González, University of Seville, Spain Félix Grande-Torraleja, University of Jaén, Spain

Antonio Leal-Millán, University of Seville, Spain Inmaculada Martín-Rojo, University of Málaga, Spain Antonio Manuel Martínez-López, University of Huelva, Spain Francisco José Martínez-López, University of Huelva, Spain Pablo A. Muñoz-Gallego, University of Salamanca, Spain
Francisco Riquel-Ligero, University of Huelva, Spain José Miguel Rodríguez-Antón, Autonomous University of Madrid, Spain

Sandra Sanchez-Cañizares, University of Cordoba, Spain Josep Francesc Valls-Giménez, ESADE, Spain

\section{Advisory Board (Other European Members)}

Tindara Abbate, University of Messina, Italy Paulo Aguas, University of Algarve, Portugal Carlos Costa, Aveiro University, Portugal Dianne Dredge, Aalborg University, Denmark Salvatore Esposito de Falco, University of Rome "La Sapienza", Italy

Sheila Flanagan, Dublín Institute of Technology, Ireland Tania Gorcheva, Tsenov Academy of Economics, Bulgaria Tadeja Jere Jakulin, University of Primorska, Slovenia Metin Kozak, Mugla University, Turkey Álvaro Matias, Lusiada University, Portugal Alfonso Morvillo, National Research Council, Italy Alexandru Nedelea, Stefan cel Mare University of Suceava, Romania

Claudio Nigro, University of Foggia, Italy

Angelo Presenza, University "G. D'Annunzio" of Chieti-Pescara, Italy

Kanes Rajah, Royal Agricultural University, United Kingdom

\section{Advisory Board (Members from the rest of the world)}

John Allee, American University of Sharjah, United Arab Emirates

Nestor Pedro Braidot, National University of La Plata, Argentina

Roberto Elias Canese, Columbia University, Rector, Paraguay

Luca Casali, Queensland University of Technology, Australia Nimit Chowdhary, Indian Institute of Tourism and Travel Management, India

Steven Chung-chi Wu, National Pingtung University of Science and Technology, Taiwán

Dianne Dredge, Southern Cross University, Australia Daniel Fesenmaier, Temple University, United States

Babu George, Alaska Pacific University, United States Dogan Gursoy, Washington State University, United States Jafar Jafari, University of Wisconsin-Stout, United States Sanggun Lee, Pai Chai University, Korea Republic of Albert Yeh Shangpao, I-SHOU University, Taiwán Pauline Sheldon, University of Hawaii, United States Germán A. Sierra-Anaya, University of Cartagena de Indias, Rector, Colombia Xiaohua Yang, University of San Francisco, United States 


\title{
UNDERSTANDING THE IMPACT OF AIRPORT SERVICE QUALITY ON PASSENGERS' REVISIT INTENTIONS AMIDST COVID-19 PANDEMIC
}

\author{
Parvinder Kour \\ Lovely Professional University (India) \\ kourparvinder123@gmail.com \\ Aruditya Jasrotia \\ Lovely Professional University (India) \\ arudityajasrotia@gmail.com
}

\begin{abstract}
Sudhanshu Gupta
J\&K Directorate of Horticulture Planning \& Marketing (India) sudhanshugupta45@gmail.com
\end{abstract}

\begin{abstract}
With the increased competitive scenario destination authorities are looking at every possible aspect for attracting the tourists by serving quality services. Airports around the world are looking for enhancing airport service quality thereby working towards overall travel satisfaction. Quality of service and consumer satisfaction is considered as critical determinant of strategic framework for determining any business performance. The current study aims to examine the impact of airport service quality on passengers' revisit intentions amidst the COVID-19 pandemic and further its association with destination selection or choice.
\end{abstract}


Crisis situations like COVID-19 immediately hit airports and therefore, it becomes absolutely essential for them to revive and adapt their services quickly according to the changing conditions. The SEM analysis was applied where satisfaction was observed as a mediator between airport service quality and travelers' intent to revisit the airport, willingness to spend at the airport as well as their intent to come and visit again the destination. To this, positive and in fact significant relation has been observed between Airport Service Quality and willingness to spend at the airport and revisit the airport as well the destination. Since airports are amongst the service providers tourism destinations, this study gives the authorities with theoretical and empirical background to consider numerous factors that the passengers are actually looking in a service or might seek in future which currently is unclear and ambiguous due to COVID-19.

\section{KEYWORDS}

Airport Service Quality; COVID-19; Consumer Satisfaction; Destination Selection; Revisit Intentions

ECONLIT KEYS

L83; L89; L93; Z31; Z33

\section{INTRODUCTION}

With the increased competitive scenario destination authorities are seeking each possible aspect for attracting tourists while offering and serving quality services. Where tourists are looking for new trends they also strive for qualities associated with them. Airports are the first place where a tourist interacts with the destination's service and its overall impression (Whipple \& Thach, 1988; Seyanont, 2011; Lin \& Chen, 2013; Latiff \& Imm, 2015) and has a major role to play in destination satisfaction (Seetanah, Teeroovengadum \& Nunkoo, 2018). To this, they are also looking for enhancing airport service quality thereby affecting overall travel satisfaction (Dennett, Ineson, Stone \& Colgate, 2000; Park, 2007). Li et al. (2017) considered the quality of service and consumer satisfaction as critical determinants of strategic framework for determining any business performance ( $\mathrm{Li}$ et al., 2017). In fact, the airports authorities around the world are now shifting towards such service practices so as to generate more revenues by increasing the other non-aviation services (Kamarudin, 2014; Lee-Mortimer, 1993).

Tourism has now emerged as a major industry which has a growth rate of $4-5 \%$ on average. Tourism is also responsible for creating $8 \%$ of the GDP globally and around $10 \%$ of employment in the world (WTO, 2020). But, on the other hand tourism industry 
is also very vulnerable to crisis situations like natural disasters, pandemics, crisis situations (Yozcu \& Cetin, 2020; Kour, Jasrotia \& Gupta, 2020). Major components in tourism industry are the airports which manage hundreds of flights on daily basis. Crisis situations like COVID-19 immediately hit airports and therefore, it's vital for them to revive and adapt their services quickly according to the changing conditions. Since, the complex airport settings are significantly influencing tourist's satisfaction, airport authorities have typically started focusing on overall airports' performance by analyzing service gaps (Smith, 2018). According to Tse, Flin and Mearns (2007), a reliable public transportation positively influences tourists' satisfaction. In context to airport service, Han (2013) realized that increased satisfaction level derives revisit intentions significantly amongst tourists. In context to this, Airport's Council International's programme for Airport Service Quality (ASQ) determines the standardization of airports around the globe for establishing passengers' satisfaction where Indian airports like Indira Gandhi International Airport (Delhi), Chhatrapati Shivaji International Airport (Mumbai), are persistent winners (Airports Council International, 2018).

Such initiatives have made the airport services more dynamic and diverse than ever before. According to Bezerra and Gomes (2015), understanding the service quality perceptions among passengers is significant with increased trends, market competition and passenger. However, the role of airport service on tourists' revisit intention and destination selection has been found to have been scarcely conducted and in fact has not yet been studied in Indian scenario, rather the studies are directed towards service satisfaction or airline service quality like Archana and Subha (2012); Nagar (2013). Extensive limitations have been forced on the air travel to reduce transmission of COVID-19 between various regions and countries. Although, according to experts as the number of patients will decrease, the air travel and airports will gradually resume their operations. Under the COVID-19 pandemic scenario, it is quite clear that the service quality is highly affected globally due to the risk of outbreaks in locations worldwide. In continuation to this, the purpose of this study is to examine the impact of airport service quality on passengers' revisit intentions amidst the COVID-19 pandemic and further its association with destination selection or choice. This present study will be helpful in current scenario for the authorities to enhance and innovate the airport 
services in future, as airports are part of overall tourism service experience and not simply a traveling entity.

\section{LITERATURE REVIEW AND HYPOTHESES DEVELOPMENT}

Surged commercialization, privatization and increased demands have raised the level of competition between airports around the globe making the service and performances of airports a very critical aspect (Jimenez et al., 2014; Gupta \& VunnamVenkaiah, 2015). To this service quality has been defined as customers overall perception about efficiency of services offered by the organizations (Chen, 2008) thereby giving the clarity about what is expected and what is being delivered (Chao, Lin \& Chen, 2013) where the passenger satisfaction with airport service is influenced with check-in procedures, waiting hall facilities, security etc. (Martín-Cejas, 2006). And all this quality service experience can enhance their satisfaction which further leads to enhanced profit, and reuse of facilities (Lai, Griffin \& Babin, 2009). Thus, the passenger satisfaction with the service not only leads to their positive behavioral intention but also directs the reuse the airport facilities and services and ultimately the destination visitation.

\section{1) AIRPORT SERVICE QUALITY AND TOURISTS' SATISFACTION}

According to Crompton and Mackay (1990) service quality is analyzed on various standards including staff, facilities and delivery. As per Wilson et al. (2012), service quality is a cognitive and subjective process which varies according to context and the presence of some factors. In this regard, passengers consider their travel as a particular experience with aircraft as well as with airport (Nijhuis, 2013). To this Harrison, Popovic and Kraal (2015) realized that for passengers, airports can be a frustrating challenge at times (Harrison et al., 2015). Service quality fundamentals of airports which include its capacity, shopping facility, availability of parking space, availability facilities at waiting halls, environment, air-conditioning, and consistent security system, are projected to establish satisfaction among passengers (Suki, 2014; Smith, 2018; Farooq et al., 2018). 
Where Sureshchandar, Rajendran and Anantharaman (2002) explained the satisfaction as a multidimensional construct, the analysis of tourism service quality starts with quality of services available at airport Martín-Cejas (2006), and hence been recognized as an essential constituent of destination satisfaction (Bezerra \& Gomes, 2015; Seetanah, Teeroovengadum \& Nunkoo, 2018) (Figure1).

H1: Airport service Quality has an impact on Tourist Satisfaction with the Destination.

\section{2) SATISFACTION AND PASSENGERS' WILLINGNESS TO SPEND AT AIRPORT}

Sensitivity towards the price is considered an important element for behavioral intention which defines consumes' willingness to pay more (Dean, Morgan \& Tan, 2002). According to Eboli and Mazzulla (2008) and dell'Olio et al. (2011), improvements in service quality influences passengers' willingness to spend for particular transport service including shops, cafes, seating etc. De Ruyter, Wetzels and Bloemer (1998) found that customers explicitly compare between their service needs and requirements and willingly pay for quality services when they meet their expectations (Demir, Talaat \& Aydinli, 2015). Industries that succeeded in providing high satisfaction among consumers have the aptitude to put high competitive edge particularly in terms of pricing (Hoffman \& Bateson, 2001). In other words, experience satisfaction amongst passengers or tourists of global airport affects their likelihood to purchase or spending at airport (including F\&B, shopping and other duty free goods) (DKMA, 2014) (Figure1).

H2: Satisfaction with Airport Quality Service influences the Passengers' willingness to spend at Airport.

\section{3) TOURISTS' SATISFACTION AND BEHAVIORAL INTENTION}

Behavioral intention has been defined by Ajzen (1985); Ajzen and Fishbein (1977) as extent to which an individual devise further plans to execute a particular behavior in 
future. During the tourism process, tourists generally analyze the benefits tagged as worthy in terms of their time and money, which determine their level of satisfaction and further influence tourists' intentions to revisit (Lee, Yoon \& Lee 2007; Ekanayake \& Gnanapala, 2016). To this Cream (2009) in his study explained the significance of service valuing to passengers needs in aviation sector to sustain the service quality at airports. Tourists' revisit intention has been explained as perceived chances of their revisiting the similar destination, thus defining tourists further behavioral intention (Cole \& Scott, 2004; Loi et al., 2017) where satisfaction acts as mediator (Ismail et al., 2017). According to Zeithaml, Berry and Parasuraman (1996), favorable service quality and experience induce positive behavioral intentions including re-visitation (Choi \& Chu, 2001). Tourists' revisit to a destination is determined by fulfilment of their needs and expectations with the services thus increasing their loyalty (Stylos et al., 2017; Saribanon et al., 2016). In other words, the dissatisfaction with the quality of services will lower tourists' satisfaction and would create a negative impact on their future behavioral intentions (Seyanont, 2011; Seetanah, Teeroovengadum \& Nunkoo, 2020; Dennet't et. al., 2000) (Figure1).

H3: Tourists satisfaction with Airport Service Quality has a significant impact on intention to reuse the airport.

H4: Tourists satisfaction with Airport Service Quality has a significant impact on their intention to revisit the destination.

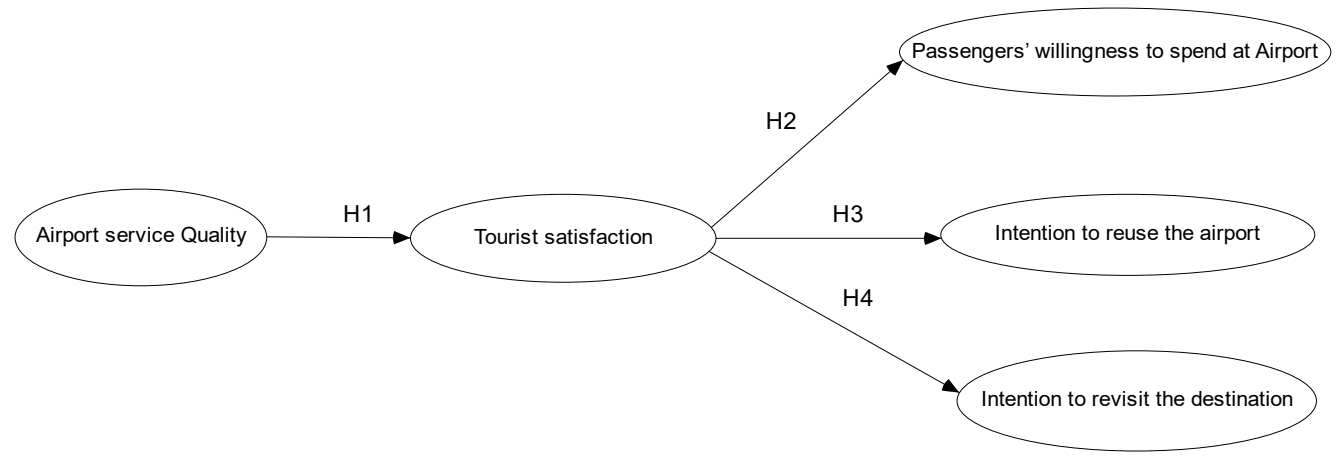

Figure 1: Theoretical Framework of the study Source: own elaboration

363 


\section{RESEARCH METHODOLOGY}

Tourism has been one of those industries which are most harshly disturbed by COVID-19. The first response to tackle a pandemic like this is to shut down operations in airports to limit human mobility.

The present research is particularly conducted on Indian airports. Before the closures due to COVID-19, Indian airports handled about 3,330 domestic and 580 international departures per day, according to the approved schedule for flights until March-end. Being a third largest aviation market in the world, India's FDI inflows air transport industry reached US\$ 1,817.23 million in December 2018 (IBEF, 2019). It has 103 operational airports with about 620 airplanes which are in fact further expected to grow to 1100 by 2027 (IBEF, 2019), thus extending a huge support to the Indian tourism industry.

Airports Council International in 2018 analyzed and ranked the various airports based on their services. Making it more directional towards the concept, it is vital that airport operatives comprehend tourists' attitudes and behavior in tourism to increase airport service quality (ASQ) in cooperation with tourism practices and, encourage re-visitation amongst tourists. India's top airports, including the two biggest hubs of New Delhi and Mumbai, are currently home to about $80 \%$ of the civilian aircraft that have had to remain on the ground since the authorities enforced a blanked flying ban in March due to the COVID-19 outbreak in the country. According to Fodness and Murray (2007), passenger's behavior and airport service experience varies with type of tourists, destinations and other related aspects. As no former research has examined the service of Indian airports with tourist's revisit intention, this framework provided an ideal setting that needs to be investigated. A period like this can be looked upon as a prospect to mend various problems in the tourism industry and changing the ways of providing services which can be most suitable for future of tourism industry (Seraphin \& Gowreesunkar, 2019). 


\section{1) DATA COLLECTION AND SAMPLING}

The study was conducted at International Airports of top five destinations ranked by WTTC (2018). The study was performed with tourists in January, February and March 2020, who departed and reached at the destinations, using the services of Indira Gandhi International Airport (Delhi), Chhatrapati Shivaji International Airport (Mumbai), Goa International Airport (Goa), Chennai International Airport (Chennai), Sardar Vallabhbhai Patel International Airport (Gujarat). This was the time when the number of cases of COVID-19 was on rise in India and the impacts of restrictions and measures taken at airports were visible. The data was gathered from the passengers at the waiting hall of targeted airports. Also, the tourists visiting these targeted destinations were approached to get high response rate. To adopt the more refined approach towards the study, the responses from passengers with 18 years or above age and have departed from these airports during these 3 months (January, February and March) only were considered for analysis. The snowball sampling method of nonprobability sampling was adopted as it allows the sampling of natural interaction units in sociological studies (Biernacki \& Waldorf, 1981).

Since the exact population traveling through the selected airport were not available especially during the pandemic, to justify the study criterion 500 sample was selected and targeted (Hair et al., 2013; Krejice \& Morgan, 1970) out of which 338 was found relevant and reliable for the analysis. As far as measurement scale is concerned, the dimensions were adopted and modified in accordance with the criterion using numerous studies conducted by Zeithaml et al. (1996); Tsai, Hsu and Chou (2011); Okumus et al. (2013); Smith (2018); Seyanont (2011), Prentice and Kadan (2019); Choi and Chu (2001); George, Henthorne and Panko (2013) and Seetanah et al. (2020). The validity of the used scale was further analyzed using SPSS 22.0 which reflects the factor loading and the alpha value thereby providing the significance of the scale for further usage (table 1 and table 2). 


\begin{tabular}{|c|c|c|c|}
\hline Dimensions & Variables & Loadings & $\mathbf{\alpha}$ \\
\hline \multirow{4}{*}{$\begin{array}{l}\text { Layout } \\
\text { Accessibility }\end{array}$} & $\begin{array}{l}\text { Baggage trolleys around the airport were safely } \\
\text { located and cleaned. }\end{array}$ & .625 & \multirow[t]{4}{*}{.747} \\
\hline & $\begin{array}{l}\text { The airport's signs clearly directed me to } \\
\text { services/facilities. }\end{array}$ & .614 & \\
\hline & $\begin{array}{l}\text { The airport's layout was safely designed to } \\
\text { cater to special needs of passengers. }\end{array}$ & .598 & \\
\hline & $\begin{array}{l}\text { Overcrowding and physical contacts were } \\
\text { avoided for easy movement specially in waiting } \\
\text { areas. }\end{array}$ & .591 & \\
\hline \multirow[t]{4}{*}{ Check-in } & $\begin{array}{l}\text { The waiting time was time consuming but was } \\
\text { acceptable. }\end{array}$ & .644 & \multirow[t]{4}{*}{.761} \\
\hline & The Check-in procedure was efficient. & .699 & \\
\hline & $\begin{array}{l}\text { Check-in Staff was helpful and guided us with } \\
\text { safety measures. }\end{array}$ & .666 & \\
\hline & $\begin{array}{l}\text { I found the self-check-in kiosks were } \\
\text { appropriately equipped with safe check-in } \\
\text { practice. }\end{array}$ & .647 & \\
\hline \multirow[t]{4}{*}{ Security } & $\begin{array}{l}\text { The waiting time during security check was } \\
\text { acceptable. }\end{array}$ & .572 & \multirow[t]{4}{*}{.803} \\
\hline & I felt safe and secure during security screening. & .616 & \\
\hline & $\begin{array}{l}\text { Security screening was as per given guidelines } \\
\text { for COVID- } 19 \text {. }\end{array}$ & .648 & \\
\hline & Security staff was helpful and courteous. & .681 & \\
\hline \multirow[t]{4}{*}{ Ambience } & $\begin{array}{l}\text { The facilities were maintained and } \\
\text { appropriately cleaned. }\end{array}$ & .791 & \multirow[t]{4}{*}{.850} \\
\hline & $\begin{array}{l}\text { Sitting arrangements were maintained as per } \\
\text { given SOP by the authorities. }\end{array}$ & .815 & \\
\hline & $\begin{array}{l}\text { Safe distance was ensured by the authorities } \\
\text { while using the seating and other facilities. }\end{array}$ & .728 & \\
\hline & $\begin{array}{l}\text { Guidelines were displayed for the tourists for } \\
\text { destination visitation amidst of COVID-19 } \\
\text { lockdown. }\end{array}$ & .744 & \\
\hline \multirow{3}{*}{ Facilities } & Washrooms/ toilets were kept clean. & .692 & \multirow{3}{*}{.879} \\
\hline & Seating and waiting arrangement were apt. & .710 & \\
\hline & $\begin{array}{l}\text { The electronic flight displays provided } \\
\text { information clearly and frequently. }\end{array}$ & .651 & \\
\hline
\end{tabular}

Dimensions

Satisfaction

\section{Variables}

Loadings

a

\begin{tabular}{|l|c|}
\hline $\begin{array}{l}\text { I am satisfied with the experiences I had } \\
\text { at this airport. }\end{array}$ & .812 \\
\hline $\begin{array}{l}\text { My choice to select travel amidst } \\
\text { pandemic from this airport was a wise }\end{array}$ & .899 \\
\hline
\end{tabular}




\begin{tabular}{|c|c|c|c|}
\hline & one. & & \\
\hline & $\begin{array}{l}\text { I did the right thing by selecting this } \\
\text { airport in this pandemic. }\end{array}$ & .876 & \\
\hline Spend at Airport & $\begin{array}{l}\text { I preferred to spend time at retail outlets } \\
\text { and Restaurants rather taking risk to go } \\
\text { outside. }\end{array}$ & .710 & .771 \\
\hline & $\begin{array}{l}\text { I invested in shopping for products at } \\
\text { airport premise rather than going out in } \\
\text { market and taking risk. }\end{array}$ & .755 & \\
\hline Intention to & $\begin{array}{l}\text { I intend to revisit this airport in the near } \\
\text { future. }\end{array}$ & .624 & .751 \\
\hline Reuse the Airport & I will re-use this airport in future as well. & .718 & \\
\hline & I am willing to travel through this airport. & .761 & \\
\hline Intention to & $\begin{array}{l}\text { My intention to visit this destination is } \\
\text { high. }\end{array}$ & .728 & .761 \\
\hline Revisit & I will revisit this destination. & .746 & \\
\hline Destination & $\begin{array}{l}\text { This destination will be my priority over } \\
\text { other destinations whenever I want to } \\
\text { travel in India and abroad. }\end{array}$ & .744 & \\
\hline
\end{tabular}

Table 2: Measurement Scale Validation for Service Quality for Satisfaction, Spending at Airport, Intention to Reuse the Airport and Intention to Revisit the Destination

Source: own elaboration

\section{DATA ANALYSIS AND INTERPRETATION}

Most of the responses were retrieved from Indira Gandhi International Airport, Delhi (55.6\%) followed by Chennai International Airport, Chennai (8.6\%) and Chhatrapati Shivaji International, Mumbai (5.9\%) and Goa International Airport (5.6\%) whereas $22.8 \%$ were received from other international airports like Amritsar International airport, etc.

As far as demographics are concerned, out of 338 respondents, 163 (48.22\%) were male and $175(51.77 \%)$ were female. Age wise most of the respondents were from the age group of $18-25$ years (42.5\%), about $26.3 \%$ were from $26-35$ years, $15.1 \%$ were from $36-45$ years and only $11.2 \%$ belonged to the age group of $46-55$ years. Qualification wise most of the respondents were having the bachelor's degree $(45.3 \%)$ which was followed up by the respondents with postgraduate degree (36.4\%). Majority of the respondents were having the income level up to $29,999(29.5 \%)$ whereas $25.1 \%$ did not wish to disclose their income. 
When asked about purpose majority were traveling with the purpose of visiting their family and friends (26.3\%) whereas about $24.6 \%$ were traveling for business and leisure. Respondents were also asked to mark the reason to select the particular airport for traveling to which majority indicated (32.2\%) flight schedule as reason along with convenience $24.6 \%$ and only gateway to and from the destination (20.4\%) (table3).

\begin{tabular}{|c|c|c|c|}
\hline Variable & Group & $\begin{array}{c}\text { No. of } \\
\text { Respondents }\end{array}$ & $\begin{array}{l}\text { Percentage } \\
\text { (approx.) }\end{array}$ \\
\hline \multirow[t]{6}{*}{ Airports } & $\begin{array}{l}\text { Chhatrapati Shivaji } \\
\text { International }\end{array}$ & 20 & 5.9 \\
\hline & $\begin{array}{c}\text { Indira Gandhi International } \\
\text { Airport }\end{array}$ & 188 & 55.6 \\
\hline & Chennai International Airport & 29 & 8.6 \\
\hline & Goa International Airport & 19 & 5.6 \\
\hline & $\begin{array}{l}\text { Sardar Vallabhbhai Patel } \\
\text { International Airport }\end{array}$ & 5 & .9 \\
\hline & Other & 77 & 22.8 \\
\hline \multirow[t]{2}{*}{ Gender } & Male & 163 & 48.22 \\
\hline & Female & 175 & 51.77 \\
\hline \multirow[t]{6}{*}{ Age } & $18-25$ & 143 & 42.3 \\
\hline & $26-35$ & 89 & 26.3 \\
\hline & $36-45$ & 51 & 15.1 \\
\hline & $46-55$ & 38 & 11.2 \\
\hline & $56-65$ & 14 & 4.1 \\
\hline & $65+$ & 3 & .9 \\
\hline \multirow[t]{5}{*}{ Qualification } & Secondary school & 16 & 4.7 \\
\hline & Diploma or trade certificate & 11 & 3.3 \\
\hline & Bachelor's degree & 153 & 45.3 \\
\hline & Postgraduate degree & 123 & 36.4 \\
\hline & Other & 35 & 8.0 \\
\hline \multirow[t]{9}{*}{ Income } & 0 to 29,999 & 100 & 29.5 \\
\hline & 30,000 to 45,000 & 53 & 15.7 \\
\hline & 45,001 to 60,000 & 51 & 15.1 \\
\hline & 60,001 to 75,000 & 12 & 3.6 \\
\hline & 75,001 to 90,000 & 12 & 3.6 \\
\hline & 90,001 to 120,000 & 16 & 4.7 \\
\hline & 120,001 to 150,000 & 8 & 2.4 \\
\hline & 150,001 and above & 1 & 0.3 \\
\hline & Do not wish to disclose & 85 & 25.1 \\
\hline \multirow[t]{6}{*}{ Occupation } & Professional & 38 & 9.5 \\
\hline & Teaching education & 56 & 16.6 \\
\hline & Managerial executive & 11 & 3.3 \\
\hline & Administrative clerical & 10 & 3.0 \\
\hline & Engineering technical & 56 & 16.6 \\
\hline & Marketing sale & 25 & 7.4 \\
\hline
\end{tabular}




\begin{tabular}{|c|c|c|c|}
\hline \multirow{4}{*}{} & Entrepreneurial self-employed & 16 & 4.7 \\
\cline { 2 - 4 } & Not currently employed & 55 & 16.3 \\
\cline { 2 - 4 } & Other & 71 & 21.0 \\
\hline \multirow{4}{*}{$\begin{array}{c}\text { Purpose of } \\
\text { travel }\end{array}$} & Leisure & 83 & 24.6 \\
\cline { 2 - 4 } & Business & 83 & 24.6 \\
\cline { 2 - 4 } & Education & 65 & 19.2 \\
\cline { 2 - 4 } & Visiting family and friends & 89 & 26.3 \\
\cline { 2 - 4 } & Other & 18 & 5.3 \\
\hline \multirow{4}{*}{$\begin{array}{c}\text { Reasons to } \\
\text { choose } \\
\text { particular } \\
\text { airport }\end{array}$} & Flight schedule & 42 & 12.2 \\
\cline { 2 - 4 } & Availability of tickets & 83 & 24.6 \\
\cline { 2 - 4 } & Convenience (traveling time) & 69 & 20.4 \\
\cline { 2 - 4 } & Only gateway to and from the & 5.3 \\
\cline { 2 - 4 } & destination & 18 & 5.0 \\
\cline { 2 - 4 } & Quality & 17 & \\
\cline { 2 - 4 } & Other & & \\
\hline
\end{tabular}

Table 3: Demographics

Source: own elaboration

\section{1) HYPOTHESES TESTING}

The validity of airport service quality was then assessed for the data collected. The second-order CFA model fit for this construct was acceptable: $\chi^{2}=689.41$, d.f. $=246$; $\mathrm{CFI}=.91 ; \mathrm{TLI}=.90 ; \mathrm{RMSEA}=.06$. The path coefficients between the indicators and their respective first-order factors were significant at the .05 level. The model fit for the second-order factor structure by conducting a one-factor CFA on the average scores of the six first-order constructs (e.g., Jayachandran et al., 2005) was $x 2=32.37$, df $=14$; $\mathrm{CFI}=.93 ; \mathrm{TLI}=.90 ; \mathrm{RMSEA}=.06$. All the path coefficients were significant at the .05 level. We therefore used the aggregated scale consisting of the average scores of the dimensions of airport service quality as their indicators for further analysis. Table 4 also justifies the dimensions' reliability and validity for further analysis process.

\begin{tabular}{|c|c|c|c|c|c|}
\hline India & ASQ & PS & SAR & IRD & IRA \\
\hline ASQ & .71 & & & & \\
\hline PS & $.26^{* *}$ & .90 & & & \\
\hline SAR & $.20^{* *}$ & $.26^{\star *}$ & .89 & & \\
\hline IRD & $.13^{*}$ & .03 & $.12^{*}$ & .82 & \\
\hline IRA & .075 & $.15^{\star *}$ & .10 & .05 & .86 \\
\hline \multicolumn{7}{r}{ Table 4: Correlations and square root of constructs' AVE }
\end{tabular}

Note: $A S Q=$ Airport Service Quality; PS = Passenger Satisfaction; SAR = Spend at Airport Retail; IRD = Intention to Revisit the Destination; IRA = Intention to Reuse the Airport; ${ }^{*} p<.05 ;{ }^{* *} p<.01$

Source: own elaboration 
The hypotheses were tested. First, airline service quality has a positive effect on passenger satisfaction $(B=.75, p<.001)$ (Table 3). Further, for Indian, passenger satisfaction only has a positive effect on spend at airport retail $(B=.26, p<.001)$, and intention to reuse the airport $(ß=.15, p<.01)$ (table 5,6 and 7 ).

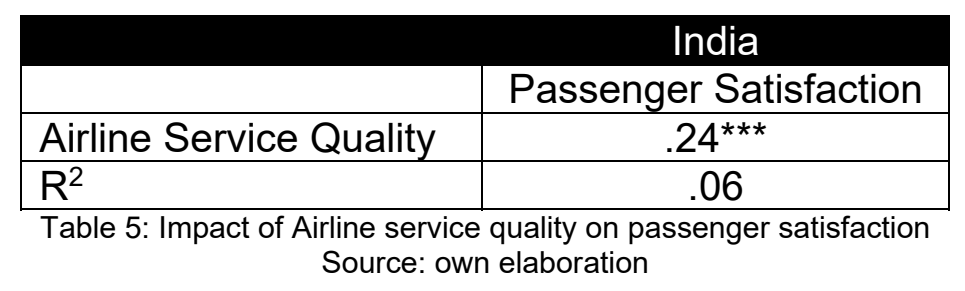

\begin{tabular}{|l|c|c|c|}
\hline & \multicolumn{3}{|c|}{ India } \\
& $\begin{array}{c}\text { Spending at } \\
\text { Airport Retail }\end{array}$ & $\begin{array}{c}\text { Destination } \\
\text { Revisit Intentions }\end{array}$ & $\begin{array}{c}\text { Airport Reuse } \\
\text { Intentions }\end{array}$ \\
\hline Passenger Satisfaction & $.26^{* * *}$ & .03 & $.15^{\star *}$ \\
\hline $\mathrm{R}^{2}$ & .07 & .00 & .02 \\
\hline
\end{tabular}

Table 6: Relationship between Passenger Satisfactions, spending at Airport, Intention to Revisit the Destination and Intention to Reuse the Airport

Source: own elaboration

\begin{tabular}{|l|c|c|}
\hline & Flight schedule (N=192) & Other (N=146) \\
\hline & Passenger Satisfaction & Passenger Satisfaction \\
\hline Airline Service Quality & $.24^{\star *}$ & $.28^{\star *}$ \\
\hline $\mathrm{R}^{2}$ & .06 & .08 \\
\hline \multicolumn{2}{|c|}{ Table 7: Impact of airline service quality on passenger satisfaction for different reasons (India) } \\
Source: own elaboration
\end{tabular}

In relation to this, the authors like Han and Hwang (2017); Kim, Park and Choi (2016) Prentice and Kadan (2019); Okumus et al. (2013) explained the relationship between service quality and spending at airport, reuse the airport and destination visit. During the analysis the similar context was taken into account for analyzing the other dimensions among customers amidst pandemic. To make it more elaborative the effect of each dimension was analyzed and accordingly elaborated in the table 8 . The effect of different dimensions of airport service quality was examined. For Indians, check-in has a positive effect on spend at airport retail $(B=.13, p<.05)$. Ambience has a positive effect on intention to revisit the destination $(\beta=.18, p<.05)$. Check-in also has a positive effect on intention to reuse the airport $(B=.12, p<.05)$ (table 8$)$. 


\begin{tabular}{|l|c|c|c|}
\hline & $\begin{array}{c}\text { Spending at } \\
\text { Airport Retail }\end{array}$ & $\begin{array}{c}\text { Destination Revisit } \\
\text { Intentions }\end{array}$ & $\begin{array}{c}\text { Airport Reuse } \\
\text { Intentions }\end{array}$ \\
\hline Layout Accessibility & -.01 & .02 & -.01 \\
\hline Check-in & $.13^{*}$ & .11 & $.12^{*}$ \\
\hline Security & .04 & .00 & -.04 \\
\hline Ambience & .15 & $.18^{*}$ & .01 \\
\hline Facilities & .03 & -.11 & .02 \\
\hline Service Personnel & .03 & -.01 & .00 \\
\hline Self-Service & .01 & .08 & .06 \\
Technologies & .05 & .04 & .02 \\
\hline $\mathrm{R}^{2}$ & \multicolumn{2}{|c|}{} \\
\multicolumn{2}{|c|}{ Table 8: Effect of different dimensions of airport service quality } \\
\hline
\end{tabular}

We further examined the effect of airport service quality based upon participants' different reasons and traveling purposes. We divided reasons into flight schedule and others, and classify traveling purposes into leisure and business.

We first looked at participants with different reason. A multi-group analysis was conducted to assess whether the examined relationships differ between flight schedule and other for Indians. The results show that the chi-square of the model with all parameters constrained for the two groups significantly differs from that of the unconstrained model $(\Delta \mathrm{X} 2(125)=206.85, \mathrm{p}<.05)$, indicating flight schedule and other are different in their perceptions of airline service quality and intentions. Airline service quality again has a significant effect for different reasons. However, passenger satisfaction' effect is not significant under the flight schedule reason, and it only significantly influences spending at airport retail under other reasons (Table 9, 10 \& 11).

\begin{tabular}{|l|c|c|c|c|c|c|}
\hline & $\begin{array}{c}\text { Spending } \\
\text { at Airport } \\
\text { Retail }\end{array}$ & $\begin{array}{c}\text { Destination } \\
\text { Revisit } \\
\text { Intentions }\end{array}$ & $\begin{array}{c}\text { Airport } \\
\text { Reuse } \\
\text { Intentions }\end{array}$ & $\begin{array}{c}\text { Spending } \\
\text { at Airport } \\
\text { Retail }\end{array}$ & $\begin{array}{c}\text { Destination } \\
\text { Revisit } \\
\text { Intentions }\end{array}$ & $\begin{array}{c}\text { Airport } \\
\text { Reuse } \\
\text { Intentions }\end{array}$ \\
\hline $\begin{array}{l}\text { Passenger } \\
\text { Satisfaction }\end{array}$ & $.27^{\star * *}$ & -.03 & $.22^{* *}$ & $.25^{* *}$ & .10 & .08 \\
\hline $\mathrm{R}^{2}$ & .08 & .00 & .05 & .06 & .01 & .01 \\
\hline \multicolumn{7}{|c|}{ Table 9: The impact of passenger satisfaction for different reasons (India) } \\
Source: own elaboration
\end{tabular}




\begin{tabular}{|l|c|c|c|c|c|c|}
\hline & $\begin{array}{c}\text { Spending } \\
\text { at Airport } \\
\text { Retail }\end{array}$ & $\begin{array}{c}\text { Destination } \\
\text { Revisit } \\
\text { Intentions }\end{array}$ & $\begin{array}{c}\text { Airport } \\
\text { Reuse } \\
\text { Intentions }\end{array}$ & $\begin{array}{c}\text { Spending } \\
\text { at Airport } \\
\text { Retail }\end{array}$ & $\begin{array}{c}\text { Destination } \\
\text { Revisit } \\
\text { Intentions }\end{array}$ & $\begin{array}{c}\text { Airport } \\
\text { Reuse } \\
\text { Intentions }\end{array}$ \\
\hline $\begin{array}{l}\text { Layout } \\
\text { Accessibility }\end{array}$ & .04 & $.16^{*}$ & .00 & -.04 & -.12 & -.02 \\
\hline Check-in & .09 & .09 & .06 & $.18^{*}$ & .11 & $.21^{*}$ \\
\hline Security & .09 & -.03 & .00 & -.05 & .04 & -.11 \\
\hline Ambience & $.28^{*}$ & $.26^{*}$ & .14 & .00 & .05 & -.14 \\
\hline Facilities & -.16 & $-.24^{*}$ & -.08 & $.26^{*}$ & .06 & -.12 \\
\hline $\begin{array}{l}\text { Service } \\
\text { Personnel }\end{array}$ & -.04 & -.07 & .05 & .09 & .06 & -.06 \\
\hline $\begin{array}{l}\text { Self-Service } \\
\text { Technologies }\end{array}$ & -.00 & .03 & .07 & .02 & .11 & .02 \\
\hline$R^{2}$ & .07 & .09 & .02 & .10 & .06 & .06 \\
\hline \multicolumn{7}{|c|}{ Table 10: The impact of dimensions of airline service quality for different reasons (India) } \\
\end{tabular}

We then looked at Indian's different traveling purposes, a multi-group analysis was conducted to assess whether the examined relationships differ between leisure and business for passengers. The results show that the chi-square of the model with all parameters constrained for the two groups significantly differs from that of the unconstrained model $\left(\Delta X^{2}(125)=259.92, p<.05\right)$, indicating leisure and business are different in their perceptions of airline service quality and intentions. Airline service quality again has a significant effect for different traveling purposes. However, passenger satisfaction' effect is not significant under the leisure purpose, and it only significantly influences spending at airport retail under the business purpose (table 11, 12 and 13). Hence, the propositions for the relationship drafted by the authors as discussed above again found to be acceptable with respect to conditional situation as COVID-19.

\begin{tabular}{|l|c|c|}
\hline \multicolumn{2}{|c|}{ Leisure $(\mathrm{N}=172)$} & Business $(\mathrm{N}=148)$ \\
\hline & Passenger Satisfaction & Passenger Satisfaction \\
\hline Airline Service Quality & $.33^{\star \star *}$ & $.19^{*}$ \\
\hline $\mathrm{R}^{2}$ & .11 & .04 \\
\hline \multicolumn{2}{|c|}{ Table 11: The effect of airline service quality on passenger satisfaction for different purposes (India) } \\
Source: own elaboration
\end{tabular}




\begin{tabular}{|l|c|c|c|c|c|c|}
\hline & $\begin{array}{c}\text { Spending } \\
\text { at Airport } \\
\text { Retail }\end{array}$ & $\begin{array}{c}\text { Destination } \\
\text { Revisit } \\
\text { Intentions }\end{array}$ & $\begin{array}{c}\text { Airport } \\
\text { Reuse } \\
\text { Intentions }\end{array}$ & $\begin{array}{c}\text { Spending } \\
\text { at Airport } \\
\text { Retail }\end{array}$ & $\begin{array}{c}\text { Destination } \\
\text { Revisit } \\
\text { Intentions }\end{array}$ & $\begin{array}{c}\text { Airport } \\
\text { Reuse } \\
\text { Intentions }\end{array}$ \\
\hline $\begin{array}{l}\text { Passenger } \\
\text { Satisfaction }\end{array}$ & $.27^{* * *}$ & .08 & $.18^{*}$ & $.26^{* *}$ & -.04 & .16 \\
\hline $\mathrm{R}^{2}$ & .07 & .01 & .03 & .07 & .00 & .02 \\
\hline \multicolumn{7}{|c|}{ Table 12: The effect of passenger satisfaction for different purposes (India) } \\
Source: own elaboration
\end{tabular}

\begin{tabular}{|l|c|c|c|c|c|c|}
\hline & $\begin{array}{c}\text { Spending } \\
\text { at Airport } \\
\text { Retail }\end{array}$ & $\begin{array}{c}\text { Destination } \\
\text { Revisit } \\
\text { Intentions }\end{array}$ & $\begin{array}{c}\text { Airport } \\
\text { Reuse } \\
\text { Intentions }\end{array}$ & $\begin{array}{c}\text { Spending } \\
\text { at Airport } \\
\text { Retail }\end{array}$ & $\begin{array}{c}\text { Destination } \\
\text { Revisit } \\
\text { Intentions }\end{array}$ & $\begin{array}{c}\text { Airport } \\
\text { Reuse } \\
\text { Intentions }\end{array}$ \\
\hline $\begin{array}{l}\text { Layout } \\
\text { Accessibility }\end{array}$ & .01 & -.04 & .05 & -.03 & .07 & -.09 \\
\hline Check-in & $.18^{*}$ & .15 & $.19^{*}$ & .05 & .07 & -.00 \\
\hline Security & .05 & -.07 & $-.19^{*}$ & .08 & .07 & $.20^{*}$ \\
\hline Ambience & .07 & $.22^{*}$ & .04 & $.28^{*}$ & .23 & -.01 \\
\hline Facilities & .13 & -.11 & -.03 & -.11 & -.19 & .05 \\
\hline $\begin{array}{l}\text { Service } \\
\text { Personnel }\end{array}$ & .08 & .06 & .05 & -.04 & -.07 & -.03 \\
\hline $\begin{array}{l}\text { Self-Service } \\
\text { Technologies }\end{array}$ & -.00 & .10 & .10 & .05 & .04 & .05 \\
\hline$R^{2}$ & .08 & .06 & .07 & .06 & .05 & .05 \\
\hline
\end{tabular}

Table 13: The impact of dimensions of airline service quality for different purposes (India)

Source: own elaboration

\section{DISCUSSION AND CONCLUSION}

Present research intends to analyze the quality of service of Indian airport and its further relation with reusing the airport services amidst COVID-19 outbreak, along with revisit intentions to the concerned destinations. Accordingly, the study was formulated with the help of theoretical as well as empirical standards to inspect relationships among Service Quality of airports, Satisfaction with the services and future travel intentions amongst travelers utilizing targeted Indian airports. The SEM analysis was applied where satisfaction was observed as mediator between airport service quality and travelers' intent to revisit the airport, willingness to spend at the airport as well as their intent to come again to the destination. Conducting the analysis for moderating influence of satisfaction is helpful in realizing the relationship between service quality 
and behavioral intentions and to understand the overall structure of relationship between service quality and behavioral intentions that can be strongly defined with particular given aspect (Frazier et al., 2004).

To this, positive and in fact significant relation has been observed between Airport Service Quality and willingness to spend at the airport and revisit the airport as well the destination. The results of this study are in accordance with the studies led by Taylor and Baker (1994), Pollack (2015), Gholipour Soleimani and Einolahzadeh (2018), Seetanah, Teeroovengadum and Nunkoo (2018). Overall, research implies service quality and tourists' satisfaction as significant elements in defining their travel behavior to opt a destination on the basis of the services offered by its allied segment like airports.

Thus, the finding revealed that during their travel, tourists have a particular perception about the destination and its service and airport services are amongst one of them, which further defines their level of satisfaction or dissatisfaction with their usage of reuse of service and visitation to particular destination. If the quality of service during and after the visit is up to the mark of their expectations and travelers receive a good value for their expenditure, then it ultimately generates satisfaction amongst them thus affecting their revisit or service reuse intentions for airport (Woodruff \& Gardial 1996; Tsafarakis, Kokotas \& Pantouvakis, 2018).

More particularly, different dimensions of airport service quality were examined to realize their impact on behavioral intentions, where check-in procedure has a positive impact on passengers' spending at airport retail as well as on their intention to reuse the airport and ambience; produces a positive impact on their intention to revisit the destination. Considering the airport service process, Fodness and Murray, (2007); Correia et al. (2008) and Martín-Cejas (2006) also realized that well-organized check-in process positively stimulates the passenger satisfaction. According to Kamarudin (2014), when passengers receives their highest levels of satisfaction with the services of an airport, their spending on retail spending also increases which ultimately increases the revenue influx and also the chances of reuse of the airport facilities time and again.

The multi-group analysis revealed that flight schedule and others significantly influences the airport service quality among passengers. The results are also inclined 
with the analysis and research conducted by Fodness and Murray (2007); Jeffrey (2014). Cheng, Fookes, Reddy and Yarlagadda (2014); David (2013); Yang, Park and Choi (2015) and accordingly the service quality found to be varied among travelers particularly on the basis of their purpose to travel, where business travelers are more particular towards their schedule and time, leisure travelers are less confined to such things. Therefore, airport authorities are required to take a due concern even at these aspects of travelers and giving much more consideration to the needs and requirement that varies among passengers and making to detailed dimensional approach into their service model. As the aviation sector in India waits for the government's nod to fully resume operations, it is currently going through a retune or reform mode. From the way airlines start operations, how customers move around an airport, to the kind of services available in future at the airports, everything is going to change in future. The airlines sector will witness a new normal.

\section{1) IMPLICATIONS AND LIMITATIONS OF THE RESEARCH}

The study extends the theoretical aspect to the present pool of literature for service quality of Indian airports and passengers' behavioral intentions with airport services and associated destinations. Also, the research provides a significant contribution to service management for destination where no such analysis has been considered with Indian destinations pertaining to the destination. Since airports are amongst the service providers tourism destinations, this study gives the authorities with theoretical and empirical background to consider numerous factors that the passengers are actually looks for in a service or might seek in future which is ambivalent due to COVID-19. While defining the destination services, the role of airports cannot be overlooked as it significantly influences the travelers'/tourists' revisit intentions. Thus, it should not be the airport management authorities that should look after the services but the destination authorities need to contribute and collaboratively form the service and its marketing to the tourists so as to attract more and more tourists to the airport service and of course to the destinations. It is very important in current crisis situation to create faithful clients which are vital for revival of tourism industry and tourism services, as loyalty of 
customers will be important in decision making process (Pektas \& Hassan, 2020; Kour et al., 2020). Therefore, understanding customers and their expectations is even more crucial in current times. It is also imperative for the destination authorities to market or highlight such service given by airports and other transport sector along with destination particular service like hotels so as to make travelers more confident on their spending and traveling practices. Many changes are going to follow regarding airport services in future due to COVID-19, like washrooms will be restricted, boarding will be slower, to maintain social distancing queues will be avoided, seats will be marked and so on.

The research also has several limitations. First, the research is limited to the selective Indian airports and their quality of service, whereas the future study with other domestic and international airports can also be taken. The data considered for this study is only limited to January, February and March 2020 and due to the lockdown restrictions and travel ban in the later part of the year the responses were not gathered that can be compared with responses during the restrictions. This study analyzed the overall service quality and behavioral intentions amongst passengers and results may vary with particular airport service quality concerns. A comparative analysis is suggested for future amongst the airports on the basis of their rankings. The present study has been conducted on service quality, satisfaction, and behavioral intention only and future study with the other aspects like service gap, passenger loyalty, image etc. is also suggested as it may give the in-depth as well as more valuable insights into the concept. Additional research on the gap analysis between passengers and the airport service quality will be helpful in providing practical support for this research, but most importantly it will help authorities airport to understand the passengers' expectations during COVID-19 crisis with not only the airport's environment but also with the destination.

\section{References}

Airports Council International. ACl World Report, 2018. Retrieved from https://aci.aero/Media/c90d15d6-dcce-4a7a-8a1e-8b6e5f8e20aa/cY- 
xRg/News/World\%20Report/2018/March/ACl\%20World\%20Report March2018.pdf [accessed 16 March 2020]

Ajzen, I. From intentions to actions: A theory of planned behavior. In: Kuhl J.; Beckmann J. (Eds.). Action control. Berlin, Heidelberg: Springer, 1985, pp. 11-39.

Archana, R.; Subha, M.V. A study on service quality and passenger satisfaction on Indian airlines. International Journal of Multidisciplinary Research, Vol. 2, No 2, 2012, pp. 50-63.

Bezerra, G.C.; Gomes, C.F. The effects of service quality dimensions and passenger characteristics on passenger's overall satisfaction with an airport. Journal of Air Transport Management, Vol. 44-45, No May-June, 2015, pp. 77-81.

Biernacki, P.; Waldorf, D. Snowball sampling: Problems and techniques of chain referral sampling. Sociological Methods \& Research, Vol.10, No 2, 1981, pp. 141-163.

Chao, C.C.; Lin, H.C.; Chen, C.Y. Enhancing airport service quality: A case study of Kaohsiung international airport. Journal of the Eastern Asia Society for Transportation Studies, Vol. 10, 2013, pp. 2235-2254.

Chen, C.F. Investigating structural relationships between service quality, perceived value, satisfaction, and behavioral intentions for air passengers: Evidence from Taiwan. Transportation Research Part A: Policy and Practice, Vol. 42, No 4, 2008, pp. 709-717.

Cheng, L.; Fookes, C.; Reddy, V.; Yarlagadda, P.K. Analysis of passenger group behaviour and its impact on passenger flow using an agent-based model. In: 4th International Conference on Simulation and Modeling Methodologies, Technologies and Applications (SIMULTECH). Vienna: IEEE, 2014, pp. 733-738. 
Choi, T.Y.; Chu, R. Determinants of hotel guests' satisfaction and repeat patronage in the Hong Kong hotel industry. International Journal of Hospitality Management, Vol. 20, No 3, 2001, pp. 277-297.

Cole, S.T.; Scott, D. (2004). Examining the mediating role of experience quality in a model of tourist experiences. Journal of Travel \& Tourism Marketing, Vol. 16, No 1, 2004, pp. 79-90.

Correia, A.R.; Wirasinghe, S.C.; de Barros, A.G. A global index for level of service evaluation at airport passenger terminals. Transportation Research Part E: Logistics and Transportation Review, Vol. 44, No 4, 2008, pp. 607-620.

Cream, F. Economic Challenges Facing Airports in an Era of Global Financial Instability, 2009. Retrieve from http://www.aciasiapac.aero/upload/service/13/self/55cb071375bad.pdf [accessed 20 May 2020].

David Mc A, B. Service quality and customer satisfaction in the airline industry: A comparison between legacy airlines and low-cost airlines. American Journal of Tourism Research, Vol. 2, No 1, 2013, pp. 67-77.

De Ruyter, K.; Wetzels, M.; Bloemer, J. On the relationship between perceived service quality, service loyalty and switching costs. International Journal of Service Industry Management, Vol. 9, No 5, 1998, pp. 436-453.

Dean, A.; Morgan, D.; Tan, T.E. Service quality and customers' willingness to pay more for travel services. Journal of Travel \& Tourism Marketing, Vol. 12, No 2-3, 2002, pp. 95-110.

dell'Olio, L.; Ibeas, A.; Cecín, P.; dell'Olio, F. Willingness to pay for improving service quality in a multimodal area. Transportation Research Part C: Emerging Technologies, Vol. 19, No 6, 2011, pp. 1060-1070. 
Demir, A.; Talaat, K.; Aydinli, C. The Relations among Dimensions of Service Quality, Satisfaction, Loyalty, and Willingness to pay more: Case of GSM Operators Service at Northern-Iraq. International Journal of Academic Research in Accounting, Finance and Management Sciences, Vol. 5, No 4, 2015, pp. 146-154.

Dennet't, C.; Ineson, E.M.; Stone, G.J.; Colgate, M. Pre-bookable services in the chartered airline industry: Increasing satisfaction through differentiation. The Service Industries Journal, Vol. 20, No 2, 2000, pp. 82-94.

DKMA. 4 ways airports can improve their retail and F\&B-The link between a great experience and spending patterns. 2014. Retrieve from http://www.dkma.com/blog/?p=232 [accessed 12 March 2020].

Eboli, L.; Mazzulla, G. Willingness-to-pay of public transport users for improvement in service quality. European Transport, No 38, 2008, pp. 107-118.

Ekanayake, I.E.; Gnanapala, A.C. Travel experiences and behavioural intentions of the tourists: A study on eastern province of Sri Lanka. Tourism, Leisure and Global Change, Vol. 3, 2016, pp. 50-61.

Farooq, M.S.; Salam, M.; Fayolle, A.; Jaafar, N.; Ayupp, K. Impact of service quality on customer satisfaction in Malaysia airlines: A PLS-SEM approach. Journal of Air Transport Management, Vol. 67, No March, 2018, pp.169-180.

Fishbein, M.; Ajzen, I. Belief, attitude, intention, and behavior: An introduction to theory and research. Reading, MA: Addison-Wesley, 1977.

Fodness, D.; Murray, B. Passengers' expectations of airport service quality. Journal of Services Marketing, Vol. 21, No 7, 2007, pp. 492-506. 
Frazier, P.A.; Tix, A.P.; Barron, K.E. Testing moderator and mediator effects in counseling psychology research. Journal of Counseling Psychology, Vol. 51, No 1, 2004, pp. 115.

George, B.P.; Henthorne, T.L.; Panko, T.R. ASQual: measuring tourist perceived service quality in an airport setting. International Journal of Business Excellence, Vol. 6, No 5, 2013, pp. 526-536.

Gholipour Soleimani, A.; Einolahzadeh, H. The influence of service quality on revisit intention: The mediating role of WOM and satisfaction (Case study: Guilan travel agencies). Cogent Social Sciences, Vol. 4, No 1, 2018, p.1560651.

Gupta, R.; Venkaiah, V. Airport passengers: Their needs and satisfaction. SCMS Journal of Indian Management, Vol.12, No 3, 2015, pp. 46.

Hair, J.F.; Ringle, C.M.; Sarstedt, M. Partial least squares structural equation modeling: Rigorous applications, better results and higher acceptance. Long Range Planning, Vol. 46, No 1-2, 2013, pp. 1-12.

Han, H. Effects of in-flight ambience and space/function on air travelers' decision to select a low-cost airline. Tourism Management, Vol. 37, No August, 2013, pp.125-135.

Han, H.; Hwang, J. In-flight physical surroundings: Quality, satisfaction, and traveller loyalty in the emerging low-cost flight market. Current Issues in Tourism, Vol. 20, No 13, 2017, pp.1336-1354.

Harrison, A.; Popovic, V.; Kraal, B. (2015). A new model for airport passenger segmentation. Journal of Vacation Marketing, Vol. 21, No. 3, 2015, pp. 237-250.

Hoffman, K.D; Bateson, J.E. Essentials of services marketing: Concepts, strategies and cases. Cincinnati, OH: South-Western College Pub, 2001. 
IBEF (India Brand Equity Foundation). Indian Airports Analysis, April, 2019. Retrieve from https://www.ibef.org/industry/indian-airports-analysis-presentation [accessed 30 April 2020].

Ismail, A.; Rose, I.R., Tudin, R.; Dawi, N.M. Relationship between Service Quality and Behavioral Intentions: The Mediating Effect of Customer Satisfaction. Etikonomi, Vol. 16, No 2, 2017, pp. 125-144.

Jeffrey, T.M. The Impacts of Customer Service Quality on Passenger Satisfaction: A Case Study of Customer Service Units in the Terminals of Kotoka International Airport (Bachelor Dissertation). Kwame Nkrumah University of Science and Technology, Ghana, 2014. Retrieve from

https://www.academia.edu/11837216/THE IMPACTS OF CUSTOMER SERVICE QU ALITY ON PASENGER SATISFACTION [accessed 20 March 2020].

Jimenez, E.; Claro, J.; de Sousa, J.P. The airport business in a competitive environment. Procedia-Social and Behavioral Sciences, Vol. 111, 2014, pp. 947-954.

Kamarudin, R.F. Managing Customer Expectation for Passenger Service at Airport. Human Resource Services, Malaysia Airports Holdings Berhad. 2014. Retrieve from http://www.aciasiapac.aero/services/main/18/upload/service/18/self/55cc68cb431f0.pdf [accessed 2 June 2020].

Kim, M.H.; Park, J.W.; Choi, Y.J. A study on the effect of airport choice attributes on airport users' satisfaction and behavioural intentions: The case of Gimpo International Airport. Journal of Airport Management, Vol. 10, No 2, 2016, pp. 145-157. 
Kour, P.; Jasrotia, A.; Gupta, S. COVID-19: A Pandemic to Tourism Guest-Host Relationship in India. International Journal of Tourism Cities, 2020, Vol. ahead-of-print No. ahead-of-print

Krejcie, R.V.; Morgan, D.W. Determining sample size for research activities. Educational and psychological measurement, Vol. 30, № 3, 1970, pp. 607610.

Lai, F.; Griffin, M.; Babin, B.J. How quality, value, image, and satisfaction create loyalty at a Chinese telecom. Journal of Business Research, Vol. 62, No 10, 2009, pp. 980986.

Latiff, K.; Imm, N.S. The Impact of Tourism Service Quality on Satisfaction. International Journal of Economics \& Management, Vol. 9, No December, 2015, pp. 67-94.

Lee, S.Y.; Petrick, J.F.; Crompton, J. The roles of quality and intermediary constructs in determining festival attendees' behavioral intention. Journal of Travel Research, Vol. 45, No 4, 2007, pp. 402-412.

Lee-Mortimer, A. Customer focus takes off. The TQM Magazine, Vol. 5, No. 3, 1993, pp. $37-41$.

Li, W.; Yu, S.; Pei, H.; Zhao, C.; Tian, B. (2017). A hybrid approach based on fuzzy AHP and 2-tuple fuzzy linguistic method for evaluation in-flight service quality. Journal of Air Transport Management, Vol. 60, No May, 2017, pp. 49-64.

Lin, Y.H.; Chen, C.F. Passengers' shopping motivations and commercial activities at airports-The moderating effects of time pressure and impulse buying tendency. Tourism Management, Vol. 36, No June, 2013, pp. 426-434. 
Martín-Cejas, R.R. Tourism service quality begins at the airport. Tourism Management, Vol. 27, No 5, 2006, pp. 874-877.

Nagar, K. Perceived service quality with frill and no-frill airlines: an exploratory research among Indian passengers. Prestige International Journal of Management \& ITSanchayan, Vol. 2, No 1, 2013, pp. 63-74.

Okumus, F.; Croes, R.; Hutchinson, J.; Bogicevic, V.; Yang, W.; Bilgihan, A.; Bujisic, M. (2013). Airport service quality drivers of passenger satisfaction. Tourism Review, Vol. 68, No 4, 2013, pp. 3-18.

Park, J.W. (2007). Passenger perceptions of service quality: Korean and Australian case studies. Journal of Air Transport Management, Vol. 13, No 4, pp. 238-242.

Pektas, S.Y.; Hassan, A. The Effect of Digital Content Marketing on Tourists' Purchase Intention. Journal of Tourismology, Vol. 6, No 1, 2020, pp 79-98.

Pollack, B.L. Are moderators of the customer satisfaction-repurchase intention relationship contingent on the service category? An exploratory investigation. Services Marketing Quarterly, Vol. 36, No 4, 2015, pp. 335-351.

Prentice, C.; Kadan, M. The role of airport service quality in airport and destination choice. Journal of Retailing and Consumer Services, Vol. 47, No March, 2019, pp. 4048.

Seetanah, B.; Teeroovengadum, V.; Nunkoo, R.S. Destination Satisfaction and Revisit Intention of Tourists: Does the Quality of Airport Services Matter? Journal of Hospitality \& Tourism Research, Vol. 44, No 1, 2018, pp. 134-148. 
Seraphin, H.; Gowreesunkar, V.G.; Platania, M. Examining the Relationship between Residents' Level of Happiness and Supportiveness to Tourism Events: Winchester (UK) as a Case Study. Journal of Tourismology, Vol. 5, No 2, 2019, pp. 1-20.

Seyanont, A. Passengers' perspective of airport service quality at Suvarnabhumi International Airport. University of the Thai Chamber of Commerce Journal, Vol. 31, No. 4, 2011, pp. 97-110.

Sitorus, B.; HS, T.I.; Saribanon, E. Through Performance-Based Planning to Improve The Service Quality of Economy-Class Trains. Jurnal Manajemen Transportasi \& Logistik, Vol. 2, No. 3, 2016, pp. 353-363.

Smith, K.K. The Impact of Airport Servicescape on Passengers Satisfaction (Executive Doctorate Dissertation). Georgia State University, Atlanta, GA, 2018. Retrieve from https://scholarworks.gsu.edu/cgi/viewcontent.cgi?article=1113\&context=bus admin dis $\underline{\mathbf{s}}$ [accessed 14 June, 2020]

Stylos, N.; Bellou, V.; Andronikidis, A.; Vassiliadis, C.A. Linking the dots among destination images, place attachment, and revisit intentions: A study among British and Russian tourists. Tourism Management, Vol. 60, No June, 2017, pp. 15-29.

Suki, N.M. Passenger satisfaction with airline service quality in Malaysia: A structural equation modeling approach. Research in Transportation Business \& Management, Vol. 10, No April, 2014, pp. 26-32

Sureshchandar, G.S.; Rajendran, C.; Anantharaman, R.N. The relationship between service quality and customer satisfaction-a factor specific approach. Journal of Services Marketing, Vol. 16, No 4, 2002, pp. 363-379. 
Taylor, S.A.; Baker, T.L. An assessment of the relationship between service quality and customer satisfaction in the formation of consumers' purchase intentions. Journal of Retailing, Vol. 70, No 2, 1994, pp. 163-178.

Tsafarakis, S.; Kokotas, T.; Pantouvakis, A. A multiple criteria approach for airline passenger satisfaction measurement and service quality improvement. Journal of Air Transport Management, Vol. 68, No May, 2018, pp. 61-75.

Tsai, W.H.; Hsu, W.; Chou, W.C. A gap analysis model for improving airport service quality. Total Quality Management \& Business Excellence, Vol. 22, No 10, 2011, pp. 1025-1040.

Tse, J.L.; Flin, R.; Mearns, K. Facets of job effort in bus driver health: Deconstructing" effort" in the effort-reward imbalance model. Journal of Occupational Health Psychology, Vol. 12, No 1, 2007, pp. 48-62.

Whipple, T.W.; Thach, S.V. Group tour management: does good service produce satisfied customers? Journal of Travel Research, Vol. 27, No 2, 1988, pp.16-21.

Woodruff, R.B.; Gardial, S. Know Your Customer: New Approaches to Understanding Customer Value and Satisfaction. USA: Wiley, 1996.

WTO. International Tourism Highlights. Çevrimiçi, 2020. Retrieve from https://www.e-unwto.org/doi/pdf/10.18111/9789284421152 [accessed 2 August 2020].

WTTC. Creating a Tourism Destination from an Airport Hub. 2018. Retrieve from https://wttc.org/Research/Insights/moduleld/1035/item/d/16/controller/DownloadRequest laction/QuickDownload [accessed 28 April 2020]. 
Yozcu, O.K.; Cetin, G. A Strategic Approach to Managing Risk and Crisis at Tourist Destinations. In: Kozak, N.; Kozak, M. (Eds.). Tourist Destination Management. Cham: Springer, 2019, pp. 273-287.

Zeithaml, V.A.; Berry, L.L; Parasuraman, A. The behavioral consequences of service quality. Journal of Marketing, Vol. 60, No. 2, 1996, pp. 31-46.

Article info: Received 09/09/2020. Accepted 11/10/2020. Refereed anonymously. 